\title{
Applying Translational Research in University-Industry Collaboration through Crab Farming for Socio-Economic Alleviation of Disadvantage Communities
}

\author{
Rugayah Hashim¹, Saiful Bahari Mohd Yusoff², Zaidi Mohd Aminuddin³, Aida Maria Ismail ${ }^{4}$ \\ ${ }^{1}$ Research \& Innovation Division, Universiti Teknologi MARA, Cawangan Selangor, Puncak Alam Campus, Malaysia \\ 2 Institute of Creative Arts \& Technology, Universiti Malaysia Sarawak, Kota Samarahan, Sarawak, Malaysia \\ ${ }^{3}$ Department of Economics, Faculty of Business and Management, ${ }^{4}$ Faculty of Accountancy, \\ Universiti Tecknologi MARA, Cawangan Selangor, Malaysia
}

guy73106@yahoo.com, mysaifu!@unimas.my, pmzaidi@yahoo.com, aidamaria430@yahoo.com

Tel of 1st Author: +6013-3852288

\begin{abstract}
Innovations can be translated into social entrepreneurship to benefit disadvantage communities. This paper narrates the social entrepreneurship project between Universiti Malaysia Sarawak (UNIMAS) and Universiti Teknologi MARA Cawangan Selangor (UCS). UNIMAS's crab cage innovation was implemented at the Pulau Salak community in Santubong, Sarawak. The social entrepreneurship expertise was provided by UCS. The translational research cum collaborative project has improved the living standards by exploiting on the built environment which is perfect for crab farming. Aquaculture as a cash crop will ensure food security and significant economic growth. Translational research projects should be the new normal after the pandemic lockdowns.
\end{abstract}

Keywords: Translational research; Social entrepreneurship; Socio-economy; Aquaculture

eISSN: 2398-42870 2020. The Authors. Published for AMER ABRA CE-Bs by e-International Publishing House, Ltd. UK. This is an open access article under the CC BYNC-ND license (http://creativecommons. org/licenses/by-nc-nd/4.0). Peer-review under responsibility of AMER (Association of Malaysian Environment-Behaviour Researchers), ABRA (Association of Behavioural Researchers on Asians) and cE-Bs (Centre for Environment-Behaviour Studies), Faculty of Architecture, Planning \& Surveying, Universiti Teknologi MARA, Malaysia.

DOI: https://doi.org/10.21834/ebpj.v5i14.2098

\subsection{Introduction}

As the world recovers from the pandemic lockdowns, most countries have to realign their economic strategies. During the lockdown period, most economies came to a standstill. y's

The socio-economy for rural areas and among disadvantaged communities is the priority for all state governments in Malaysia. Assistance in building the economy has ranged from subsidies to expert advice from both the relevant government agencies as well as from universities. For university researchers, applying knowledge from basic theory to improve the living standard of disadvantaged communities has been a challenge in getting the right community and the right assistance. However, in the case of the community at Pulau Salak, Santubong, Sarawak, crab farming was the perfect match between the location and a Universiti Malaysia Sarawak's (UNIMAS) innovation testing project. Hence, this paper aims to describe the translational research project that has uplifted the socioeconomy of a rural community at Santubong, Sarawak, Malaysia. After two years, crab farming has become a significant economic endeavor as the areas of Pulau Salak provided the marine species with an apt ecosystem. Through the collaboration between UNIMAS, UiTM Sarawak, and UCS from establishing the right community, training, and marketing of the matured crabs, the socio-economy of the families involved in crab farming has improved significantly. This is evidence in the purchase of new boats and fishing equipment as well as other household amenities such as refrigerator, television sets, cell phones, accessibility to satellite television and the internet, etcetera. It is proven that establishing partnerships between universities with industries (investors and entrepreneurs) will be beneficial to all stakeholders. Industries interested in utilizing the vast expertise in both UiTM and UNIMAS have shown project success with the

eISSN: 2398-4287@ 2020. The Authors. Published for AMER ABRA cE-Bs by e-International Publishing House, Ltd., UK. This is an open access article under the CC BYNC-ND license (http://creativecommons.org/licenses/by-nc-nd/4.0). Peer-review under responsibility of AMER (Association of Malaysian Environment-Behaviour Researchers), ABRA (Association of Behavioural Researchers on Asians) and cE-Bs (Centre for Environment-Behaviour Studies), Faculty of Architecture, Planning \& Surveying, Universiti Teknologi MARA, Malaysia.

DOI: https://doi.org/10.21834/ebpj.v5i14.2098 
inclusion of international partners. The results from the collaboration have shown that a disadvantaged village in Pulau Salak, Santubong, Sarawak, has been impacted by the translational research activity. In other words, the demonstration of the impact of research as part of public sector expenditure on research grants to universities is accounted for. It is hoped that other universities will collaborate by matching different expertise to match the community concerned and provide a win-win situation for all parties. Translating research for the social and economic benefit has been materialized in the project collaboration; UNIMAS experimented while UiTM Sarawak was involved in the data collection, marketing, and promotion of the output. As of this writing, the farmed crabs have had local orders and export interest to other countries. It is recommended that other universities collaborate towards translational research in fulfilling the strategies and key performance indicators of their respective entities. In doing so, the enhancement of the knowledge transfer program and commercialization of public sector research is evidenced through a new source of income generation. Furthermore, creating a business from the research is the ultimate achievement for any university as the outcome impacts the well-being of the community. Unlike standard translational research, the analysis moves from the laboratory to the applied realm, where applied questions inspire research on underlying mechanisms. When based on and contributing to an analysis, applied research on token economies. nlike standard translational research, the analysis moves from the laboratory to the applied realm, where applied questions inspire research on underlying mechanisms. When based on and contributing to an analysis, applied research on token economies can be on the leading edge of theoretical advances, helping set the scientific research agenda (Hackenberg, 2018).

\subsection{Research Objectives}

This paper aimed to highlight the social entrepreneurship project through crab farming by the disadvantaged communities located at Pulau Salak, Santubong, Sarawak. The implementation of an innovation from UNIMAS resulted in the success of one social entrepreneurship project. through box cages placed at Pulau Salak, Santubong. In line with the purpose, the research objectives were to describe an example of a collaborative effort originating from an innovative design that has been translated into social entrepreneurship. In other words, the espoused process of translational research is detailed to showcase the significant impact of innovation on crab farming. Also, this is incorporate the application of marketing essentials for international entrepreneurship

\subsection{Literature Review}

\subsection{About translational research}

Translating research findings that impact the community and industry have been slow and mediocre (Ahmad, Rahmat, Hashim, \& Saedah, 2013). However, the research culture for translational research has started to show positive impacts on local and international communities (Rahman, 2016). Capitalizing on the advantages of translational research, public organizations, especially universities, are given a substantial investment in translating the outcomes to impact the organizational practice (Bentzen Tina, 2019). The conversion and implementation of an innovative product and process that improved and support current practices are what translational research is all about (Savory \& Fortune, 2015). The value of conducting translational research is in the form of pervasive influence (ibid), but what is translational research? According to Fort, Herr, Shaw, Gutzman, and Starren (2017), translational research as a concept has been widely used and applied in the scientific literature for more than a decade. Into the 21st century, translational research was meant for advances in the biomedical sciences so that discoveries can be "translated" into positive impacts on human health (ibid). For the social sciences, embarking on translational research through university-community partnership requires trust (Kim et al.). However, for the collaborative project, trust was already in place between UNIMAS and the Pulau Salak community. That facilitated the progress of the crab-farming project to a higher level. As posited by Kim et al., once trust is established, the likelihood of enhanced cooperation between academic and community partners increases by fostering engagement in research with mutual benefit to both parties.

\subsection{Social entrepreneurship}

The area of social entrepreneurship is not new. Attempts at new theories for the advancement of scholarly research in social entrepreneurship has been acknowledged by Santos (2012). However, the intention and goals for social entrepreneurship remain the same: the pursuit of sustainable solutions to neglected problems with positive externalities (ibid). On the other hand, Seelos and Mair (2005) stated that social entrepreneurship is an innovative model with a mission to change society. In this case, social entrepreneurship is expected to ameliorate poverty (Bruton, Ketchen, \& Ireland, 2013). By meeting the disadvantaged communities and understanding their predicaments, social entrepreneurship will capitalize on the community's natural resources and use other sustainable and regenerative approaches (Dentchev et al., 2016). Social entrepreneurship contributes directly to sustainable development goals, which inherently encourages established corporations to take on greater social responsibility (Seelos \& Mair, 2005). Undertaking social entrepreneurship will lead to significant changes in the social, political, and economic contexts for disadvantaged communities (Alvord, Brown, \& Letts, 2004).

\subsection{Insights into university-industry-community collaboration}

Any collaborative projects are not without challenges. In undertaking the university-industry-community collaboration, the social entrepreneurship project is littered with challenges. As an example, Díaz-Pichardo, Cantú-González, López-Hernández, and McElwee (2012) discussed the problems associated with developing a collaborative enterprise with farmers in Mexico. Applying the same situation with this project where the three-way relationship requires commitment, the challenges include having a fixed schedule for visits to the crab farming location. A lapse in the visits is a cause of concern as monitoring the crabs' growth is crucial for a successful social 
entrepreneurship project. The regular visits will allow the principal researcher from Universiti Malaysia Sarawak (UNIMAS) and researcher from Universiti Teknologi MARA (UiTM) Sarawak to be updated on the mud crabs' growth rates and infrastructure including imparting knowledge to the community partner on entrepreneurial development and competency. Educating the community partners on the crab-farming project is a two-way learning process and the foundation of translational research for the stakeholders. The associative behavior of the community and the university researchers is a critical element of the social entrepreneurship transformation and success (ibid).

For this paper, the theoretical underpinnings are the Community-based Participatory Research Model, which is the partnership model advocated by Ross et al. (2010). The researchers' collaborative challenge from UNIMAS and UiTM Sarawak was similar: reciprocal trust. The original goal is for both parties to benefit; research and innovation success for the researcher and socio-economic enhancement for the community. However, delineating the expectations and documenting the terms both parties is recommended (ibid). The ultimate achievement of harnessing science and securing societal impacts (Demeritt, 2010) is the same for most university researchers who have received public funding.

\subsection{Crab farming}

Farming is not limited to agriculture; farming marine species in their natural settings is the best fit but is littered with challenges. For this collaborative, translational project between the university and community, attempting a crab farming endeavor is a challenge. Finding the right community and location were the early challenges. In this case, the UNIMAS researcher was able to identify these essential factors and has successfully implemented the innovative, pre-test equipment in crab farming.

The identification of the right community was made by selecting the B40 (below 40 income) population. The community should live in a reachable location by road and located by the coastal waters of Kuching-Santubong, Sarawak. In this case, the community selected was the water village at Pulau Salak, Santubong, Sarawak (Fig. 1). These people faced unstable income as fishermen, especially during the monsoon season. At the same time, the individuals chosen to participate in the crab farming project were those who are already relying on their additional income as mud crab seekers. From here, the researchers were able to evaluate the best practices on the life cycle of the giant mud crabs (Scylla serrata) including the feed management of the mud crabs, and harvesting the mud crabs based on the artisanal, crab seekers' methods. It is crucial to identify the right individuals to be involved to ensure the project's success as part of the sustainable livelihood approach, that is, the identification of the assets that the local communities rely on and the risks that they are subjected to in small-scale, artisanal fisheries management (Apine, Turner, Rodwell, \& Bhatta, 2019). The advantages of having the artisanal crab seekers farming the crabs including having direct expertise in crustaceans husbandry, natural water quality, and nutrition control (Government, 2020). Also, scheduled visits to the site by the researchers were done for monitoring and data collection.

In a crab farming endeavor, the type of crab chosen is important from the return on investment perspective. From literature, the giant mud crabs (Scylla serrata) have a sustainable potential for capacity building (Mirera, Ochiewo, \& Munyi, 2014), depending on the geographic region. For Malaysia, mud crab farming is a limited, small-scale aquaculture activity as the built environment is the crucial factor in achieving significant income. However, the demand for the giant mud crabs is high, especially before major festivals, which means that price variations exist (ibid). Consequently, the support from relevant government agencies will ensure that mud crab farming can become a potential income generation project for rural coastal communities.

The choice of the mud crabs (Scylla serrata), as a community's potential source of income, has shown to be very promising. As evidenced by the Queensland Government (2020), giant mud crab (Scylla serrata) has excellent investment potential due to its fast growth, and good market acceptability, and price. Besides, mud crabs have good export potential and opportunities to in develop new mud crab products, such as soft-shell crab (ibid). The knowledge sharing of this paper in translational research projects and collaborative efforts between two universities in Malaysia will hopefully result in other income-generating activities sp0.anning both the domestic and international markets.

\subsection{Methodology}

\subsection{Theories}

This paper provides insights from an existing translational research project involving two public universities, a community, and an industry. Inherently, the project is founded on these theories: the implementation theory and the institutional theory. The implementation theory for translation research project uses the variables and concepts of execution that allowed the smooth transition of activities from the planning stage to project success. On the other hand, the institutional theory has succeeded in becoming the dominant theory to study macro-organizational phenomena (Suddaby, 2010). Much like social entrepreneurship, social innovations are needed to confront complex social problems as they feature substantial interdependencies (van Wijk, Zietsma, Dorado, de Bakker, \& Martí, 2019) among the variables as seen in this translational research project. Nevertheless, these theories, as advocated by (Bentzen Tina, 2019), where the dimensions provide the robustness of the translational diamond as the success of the collaborative projects depend on the level of strategic and local anchoring. The methodological activities for this project is chronologically addressed from the innovation process, the reporting of initial success and, marketing attempts.

\subsection{Innovation process}

The innovation process began with the identification of problems whereby there was a need to assist the B40 group to increase their income, especially during the monsoon season. The innovation aims to produce a low cost and essential maintenance product for the 
selected community. Observation and interviews were conducted on the area, and the people to ensure the suitability of product design matches the identified requirements. Consideration of the house located by the riverbank is crucial for efficient monitoring. The design of the crab house product is also based on the high tide and low tidewater. This resolved the issue of land area scarcity. To create a sustainable income, each incubator was offered three crab house products that can occupy almost 150 mud crab (Grade C). This crab house product was designed based on a smart storing approach.

\subsection{Reporting initial success}

The first phase of product development was installing one set of crab house products consisting of 3 crab houses. At the initial stage, only $30 \mathrm{Grade} \mathrm{C}$ mud crab was placed in one of the units. The other two units were left out for the next stage of the crab growing process. During week one, several crabs did not survive, but the rest of the crabs were alive, with less than $10 \%$ mortality rate achieved. The crabs were also able to hide in their compartment and swim freely during the high tide. The feeding sessions were done smoothly by the incubator, and the crabs would take their food to their compartment without fighting. The cleaning of the product was also easy to do and maintain. With the crabs hidden in their compartment, it was easy to identify and monitor the crab growth progress.

\subsection{Marketing attempts}

Attempts at marketing the mature crabs were through invitations by the lead researcher from UNIMAS. The family of the leading partner at the crab farm will prepare a popular local dish using the crabs as the main ingredient. A taste test through a luncheon spread to about 20 visitors will ensue. From here, the marketing is done through word of mouth of the invitees. Having fresh crab served at the location where they are farmed is a tantalizing activity. With so many pictures taken at the luncheon, the invitees will share the pictures with their social media network, and the marketing of the crabs will snowball. There is limited need to go with conventional marketing for the crabs at the local level. However, marketing and importing the crabs require proper procedures and a different set of promotional activities.

\subsection{Results}

Using the crab house to fatten the mud crabs, the growth of crabs became faster (3-week duration to grow Grade $C$ to $G$ rade $B$ ), and the incubators were able to generate extra income selling bigger sized crabs. The crab size could reach to size Grade $A$ and Grade Premium with above $600 \mathrm{~g}$ each to $1.2 \mathrm{~kg}$ in weight. The income did come from the selling of fresh crab and the cooked crab dish. By owning the crab houses, the incubators were also able to invite potential customers to visit their crab cages and dine freshly cooked crab dishes. The crab house can also be used by incubators as stock up storage units for the festive season, where the price of crab is usually higher. The income of incubators has increased by more than $100 \%$. The crab house product has won many awards, and the most prestigious award was the Malaysia Commercialization Year Award (MCY 2018) for Social Entrepreneur Category.

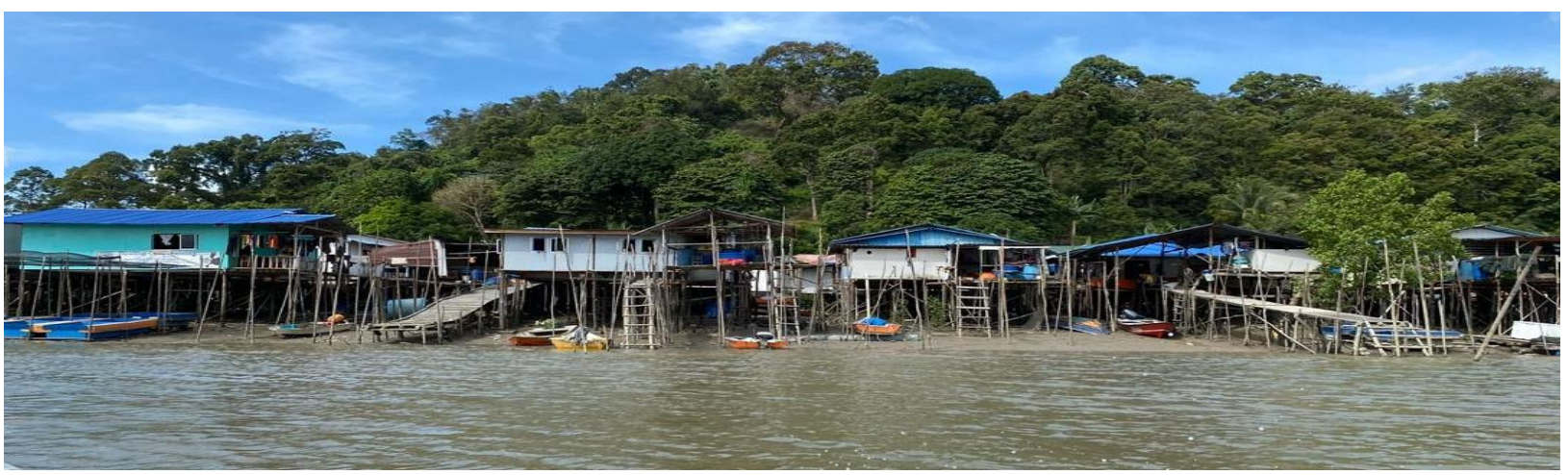

Fig. 1: Built environment for crab farming at the water village, Pulau Salak

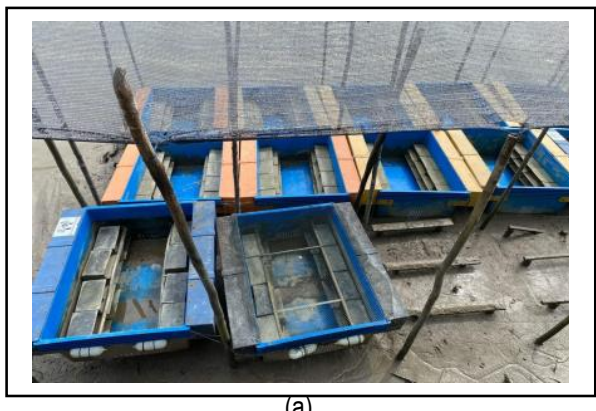

Fig. 2. (a) Crab cages during low tide; (b) Floating crab cages during high tide.

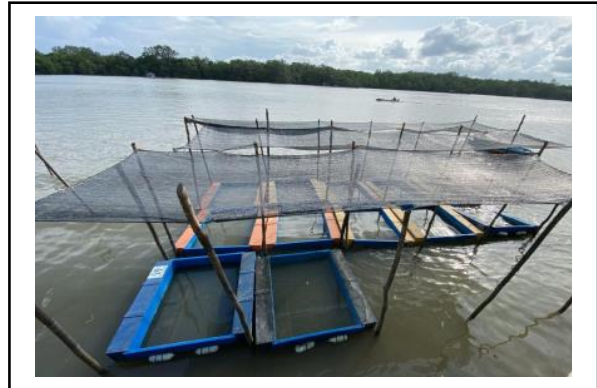

(b)

(Source: Yusoff, 2020) 


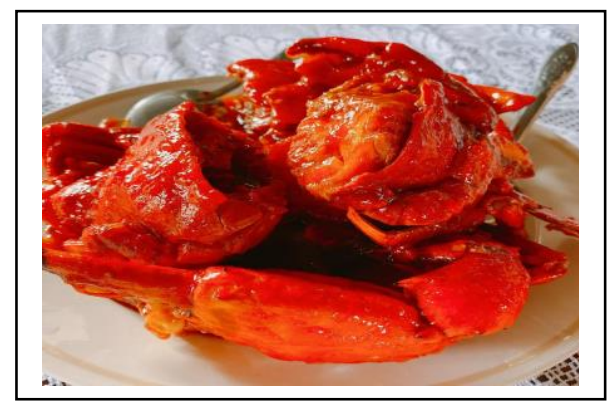

Fig. 2. (c) Chili crab dish (Copyright: Hashim, 2020)

\subsection{Illustrations}

The above illustrations evidenced the findings for this paper. Figure 1 shows the suitability of the built environment of the water village at Pulau Salak. In this case, only one villager or incubator has been identified for the project implementation of the giant mud crab farming activities. For the past two years, the incubator has been successful with crab farming as a source of sustainable income. The crab farmer's household assets have increased, such as the availability of electrical home appliances, fiberglass boat and a new engine. Proper financial records management has allowed for micro-financing and bank loans to expand the business.

For Figures $2 a$ and $2 b$, the crab cages are shown during low and high tides. The cages are secured to young mangrove trunks to ensure that the cages do not float away during tidal changes. Even in extremely high tides, the cages will float securely in between the mangrove trunks. Figure $2 \mathrm{c}$ showcases a popular dish cooked by the crab farmer's spouse, the chili crab. Prior reservations are required for visitors to have special lunch sessions at the crab farmer's home. Word of mouth and social media promotions have resulted in weekly reservations, and these events have gradually become a tourist attraction. As such, the elements of social entrepreneurship are fulfilled.

\subsection{Discussion}

The crab farming project was the result of innovative equipment in the form of a boxed cage made of durable, floating material. The cage is crocodile resistant as the coastal area is a salt-water crocodile habitat. The cage is also resistant to fierce natural elements such as strong winds, storms, and waves. Also, the internal compartments of the cage will ensure that the mud crabs will not be able to escape, but small crustaceans such as the shrimps can crawl in, and that becomes the crabs' sustenance. The project's viability is shown from the number of cages built. Also, the success of the pioneer crab farmer has perked the interest of other villagers to be involved in mud crab farming using the same technique. With the increase in mud crab supply, the next phase will involve exporting the products. There has been interest shown at the international level. Thus, further management strategies are required. Local agencies' involvement will also assist with the project's success and expand social entrepreneurship among disadvantaged communities. Another food for thought is the immediate returns when one works from home. At the time of writing, the movement control order from the Covid19 pandemic is still in place. Would-be entrepreneurs could use the time at home and lockdown period to embark on crab farming if the built environment permits. The post-Covid19 provides an excellent opportunity to farm for crabs because of the short-term income generation due to the fast growth and good market acceptability (Government, 2020).

\subsection{Limitations of Study}

The paper describes the implementation of a translational study cum collaborative project between three partners; the two universities involved, the community, and the industry. Hence, there is a limitation to this project, as there is no empirical evidence. Further research is recommended with quantitative or qualitative designs to support the community project.

\subsection{Conclusion and Recommendations}

The collaboration between university, community, and industry is possible through social entrepreneurship. The crab-farming project initiated by UNIMAS provided the impetus for educating and developing the disadvantage communities with entrepreneurial skills. The inclusion of UiTM Sarawak and UCS in assisting with the expansion of the project and its marketing has shown good collaboration between the two public universities. Finding a market for the crabs has provided the opportunity for international collaboration for these two universities. The respective objectives for the stakeholders are clearer than at the beginning of the project. The community involved started with just one family but has expanded to others in the same sea village. The social entrepreneurship project has been effective in alleviating the community from poverty. The socio-economy of the community at Pulau Salak, Santubong, Sarawak, has improved 
significantly, hence stoking the interests of other, similar communities to be part of the collaboration. Working together as one requires good leadership, and the government's intervention would further improve the livelihood and quality of life of disadvantaged communities.

\section{Acknowledgements}

The researchers would like to thank Universiti Teknologi MARA Cawangan Selangor (UCS), Puncak Alam Campus, and Universiti Malaysia Sarawak (UNIMAS) for the collaborative effort. We are also indebted to the fishing community at Pulau Salak, Santubong, Sarawak, for their commitment. We are also grateful to the industry representative based in Seoul, South Korea, for the interest in being part of the project. This project is self-funded.

\section{References}

Ahmad, S. S., Rahmat, M. N., Hashim, R., \& Saedah, N. (2013). The progress of Malaysian translational social science and humanities research: From research to practice. Paper presented at the Asia Pacific International Conference on Environment-Behavior Studies, University of Westminster, London, United Kingdom.

Alvord, S. H., Brown, L. D., \& Letts, C. W. (2004). Social Entrepreneurship and Societal Transformation:An Exploratory Study. The Journal of Applied Behavioral Science, 40(3), 260-282. doi:10.1177/0021886304266847

Apine, E., Turner, L. M., Rodwell, L. D., \& Bhatta, R. (2019). The application of the sustainable livelihood approach to small scale-fisheries: The case of mud crab Scylla serrata in South west India. Ocean and Coastal Management, 170, 17-28. doi:10.1016/j.ocecoaman.2018.12.024

Bentzen Tina, O. (2019). The translational diamond: robust translation of magic concept in public organizations. International Journal of Public Leadership, $15(2), 94-112$. doi:10.1108/IJPL-11-2018-0056

Bruton, G. D., Ketchen, D. J., \& Ireland, R. D. (2013). Entrepreneurship as a solution to poverty. Journal of Business Venturing, 28(6), 683-689. doi:https://doi.org/10.1016/j.jbusvent.2013.05.002

Demeritt, D. (2010). Harnessing Science and Securing Societal Impacts from Publicly Funded Research: Reflections on UK Science Policy. Environment and Planning A: Economy and Space, 42(3), 515-523. doi:10.1068/a42440

Dentchev, N., Baumgartner, R., Dieleman, H., Jóhannsdóttir, L., Jonker, J., Nyberg, T., . . Tang, X. (2016). Embracing the variety of sustainable business models: social entrepreneurship, corporate intrapreneurship, creativity, innovation, and other approaches to sustainability challenges. Journal of Cleaner Production.

Díaz-Pichardo, R., Cantú-González, C., López-Hernández, P., \& McElwee, G. (2012). From Farmers to Entrepreneurs:The Importance of Collaborative Behaviour. The Journal of Entrepreneurship, 21(1), 91-116. doi:10.1177/097135571102100104

Fort, D. G., Herr, T. M., Shaw, P. L., Gutzman, K. E., \& Starren, J. B. (2017). Mapping the evolving definitions of translational research. Journal of clinical and translational science, 1(1), 60-66. doi:10.1017/cts.2016.10

Government, Q. (2020). Mud crab aquaculture. Business Queensland. Retrieved from https://www.business.qld.gov.au/industries/farms-fishingforestry/fisheries/aquaculture/species/mud-crab

Kim, M. M., Cheney, A., Black, A. S., Thorpe, R. J., Cene, C. D., Dave, G. J., . . Corbie-Smith, G. Trust in Community-Engaged Research Partnerships: A Methodological Overview of Designing a Multisite Clinical and Translational Science Awards (CTSA) Initiative. Evaluation \& the Health Professions, 0(0), 0163278718819719. doi:10.1177/0163278718819719

Mirera, D. O., Ochiewo, J., \& Munyi, F. (2014). Social and economic implications of small-scale mud crab (Scylla serrata) aquaculture: The case of organised community groups. Aquaculture International, 22(4), 1499-1514. doi:10.1007/s10499-014-9762-x

Rahman, D. (2016). 10 things about Malaysia's research \& development landscape you need to know. The Star. Retrieved from https:/www.thestar.com.my/opinion/online-exclusive/whats-your-status/2016/12/23/10-things-about-malaysias-research-development-landscape-you-need-to-know/

Ross, L. F., Loup, A., Nelson, R. M., Botkin, J. R., Kost, R., Smith, G. R., \& Gehlert, S. (2010). The Challenges of Collaboration for Academic and Community Partners in a Research Partnership: Points to Consider. Journal of Empirical Research on Human Research Ethics, 5(1), 19-31. doi:10.1525/jer.2010.5.1.19

Santos, F. M. (2012). A Positive Theory of Social Entrepreneurship. Journal of Business Ethics, 111(3), 335-351. doi:10.1007/s10551-012-1413-4

Savory, C., \& Fortune, J. (2015). From translational research to open technology innovation systems. Journal of Health Organization and Management, 29(2), 200-220. doi:10.1108/JHOM-01-2013-0021

Seelos, C., \& Mair, J. (2005). Social entrepreneurship: Creating new business models to serve the poor. Business horizons, 48(3), $241-246$.

Suddaby, R. (2010). Challenges for Institutional Theory. Journal of Management Inquiry, 19(1), 14-20. doi:10.1177/1056492609347564

van Wijk, J., Zietsma, C., Dorado, S., de Bakker, F. G. A., \& Martí, I. (2019). Social Innovation: Integrating Micro, Meso, and Macro Level Insights From Institutional Theory. Business \& Society, 58(5), 887-918. doi:10.1177/0007650318789104 